\title{
Community empowerment model of coastal border based on ecotourism
}

\section{Model pemberdayaan masyarakat perbatasan pantai berbasis ekowisata}

\author{
Toto Sugito, Adhi Iman Sulaiman, Ahmad Sabiq, Muslih Faozanudin, \& Bambang Kuncoro \\ Department of Communication, Faculty of Social and Political Sciences, \\ Universitas Jenderal Soedirman \\ Address: Jalan Profesor DR HR Boenyamin No.708, Purwokerto, Central Java 53122 \\ E-mail: totomyounsoed@gmail.com
}

\begin{abstract}
Development in coastal areas is an essential priority for overcoming social and economic gaps and conflicts through empowerment programs. The purpose of this research is to create a model of ecotourism-based coastal community empowerment. This study uses the Participatory Rural Appraisal (PRA) qualitative research method by collecting data through in-depth interviews, observation, documentation analysis, Focus Group Discussion (DKT) and Participatory Decision Making (PDM). Research locations in the border area of West Kalimantan are Sebubus Village and Temajuk Village, Paloh District, Sambas Regency. The informants of this study were 35 people consisting of empowerment activists, community leaders, village government, business groups, academics, and tourists. Research data were analysed using a SWOT analysis. The results showed 1) To develop the potential of mangrove forest ecotourism and processing of food from mangrove fruit, sea turtle breeding, and coastal inheritance, participatory empowerment programs are needed; 2) Youth activists become activists of empowering ecotourism with community leaders needing support and cooperation with village and regional governments, as well as the private sector; and 3) The need to improve road infrastructure, electricity and telecommunications signals, especially in Temajuk Village so as not to cause social and economic dependence and jealousy with the Malaysian border area.
\end{abstract}

Keywords: coastal border village; ecotourism; participatory; development; community empowerment

\begin{abstract}
Abstrak
Pembangunan di wilayah perbatasan pesisir menjadi prioritas penting untuk mengatasi kesenjangan dan konflik sosial dan ekonomi melalui program pemberdayaan. Tujuan penelitian untuk membuat model pemberdayaan masyarakat perbatasan pesisir berbasis ekowisata. Studi ini menggunakan metode penelitian kualitatif Participatory Rural Appraisal (PRA) dengan pengumpulan data melalui wawancara mendalam, pengamatan, analisis dokumentasi, Diskusi Kelompok Terpumpun (DKT) dan Participatory Decision Making (PDM). Lokasi penelitian di daerah perbatasan Kalimantan Barat yaitu Desa Sebubus dan Desa Temajuk, Kecamatan Paloh, Kabupaten Sambas. Informan penelitian ini sebanyak 35 orang yang terdiri dari aktivis penggiat pemberdayaan, tokoh masyarakat, pemerintah desa, kelompok usaha, akademisi, dan wisatawan. Data penelitian dianalisis menggunakan analsis SWOT. Hasil penelitian menunjukkan 1) Untuk mengembangkan potensi ekowisata hutan mangrove dan pengolahan bahan makanan dari buah mangrove, penangkaran penyu, serta wisiata pantai dibutuhkan program pemberdayaan secara partisipatif; 2) Aktivis pemuda menjadi penggiat pemberdayaan ekowisata dengan tokoh masyarakat membutuhkan dukungan dan kerjasama dengan pemerintah desa dan daerah, serta pihak swasta; dan 3) Perlunya perbaikan infrastruktur jalan, penerangan listrik dan sinyal telekomunikasi khususnya di Desa Temajuk supaya tidak menimbulkan ketergantungan dan kecemburuan sosial dan ekonomi dengan daerah perbatasan Malaysia.
\end{abstract}

Kata kunci: desa perbatasan pesisir; ekowisata; partisipatif; pembangunan; pemberdayaan masyarakat

\section{Introduction}

The West Kalimantan region is nicknamed as the "Thousand Rivers" province because it has hundreds of large and small rivers that often passed through by sailing boats. Malaysia's Sarawak state borders this region, and according to the report of the Directorate General of Development of Disadvantaged Regions in 2017, one of its districts, Sambas is still one of the disadvantaged areas. In addition, Salim (2011) using spatial analysis, stated that Sambas District is a region with low human, social 
and agricultural development level. Sarosa (2011) states that most of the border areas are weak and underdeveloped, but the focus of border area problem is on security. The authors' study in 2018 found that people in the border areas that people in the border areas such as in Sebubus Village and Temajuk Village, Paloh Subdistrict, Sambas District, West Kalimantan, still lack awareness and ability to cultivate the resources potential of natural resources or the environment, especially plantations, beaches and tourism. Moreover, infrastructure access, such as roads and bridges are poor. If there is rain as we experienced ourselves, then people riding vehicles have difficulty in passing the bridge or road where most of the roads are still soil which has not been covered by the asphalt.

One of the main problems in Temajuk Village is infrastructure access of vehicle from the Sekura River Crossing Pier to Sebubus Village. It is paved but badly damaged by heavy trucks carrying oil palm to sent to processing plants. In addition, from the Ceremai River Crossing Pier to Temajuk Village road access is still in the form of land or not asphalted, which resulted in the difficulty of access when it rains. Temajuk village can only be passed in the morning until late afternoon because at night the road is difficult to pass because of no street lighting. However, the current road widening process is still going to be as comprehensive as 10 meters.

Meanwhile, the distance from Temajuk to Telok Melano Sarawak Malaysia is closer and better access road compared with the condition from Temajuk Village to Sebubus Village. Telok Melano is about $2 \mathrm{~km}$ from Temajuk while Sebubus is about $40 \mathrm{~km}$ away. In the village of Temajuk, the access road to the sights, especially to Atong Bay, is still confusing and very steep and slippery, in case of rain. Except, by using a motorcycle that passes the coastal path. Another obstacle is that there is no street lighting, even in Atjoe Bay tourist sites people still rely on generators for lighting.

Apart from all its limitations, Temajuk Village has many tourism potentials, and especially it is gorgeous and still natural beaches with its white sand, coastal rocks, crystal clear seawater and scenery. It also has the unique culinary potential of fresh fish with many choices in the Camar Bulan fish market which is also the place of interaction and transactions of Melano Sarawak Malaysian community and Temajuk community to trade fish either using ringgit or rupiah. Sometimes Temajuk people often buy daily necessities such as cooking oil, sugar, rice, and gas to Malaysia's Melano region because the price is more affordable than the distance is closer. Therefore, it is interesting to research Temajuk Village, Paloh Subdistrict, Sambas District, especially about the formulation of community empowerment strategy in coastal border management for social resilience and economic strengthening. As stated by Huruswati el al. (2012), development programs should be more focused on accelerating regional development where social conditions, economic culture, regional finance, accessibility and availability of infrastructure are still lagging. Therefore it needs approach or development strategy in order to improve people's welfare. Sutaat (2012) asserted that people who access public services are generally still limited, in addition to the lack of ability to manage agriculture and plantation and the limited physical infrastructure and social welfare problems. Gevisioner et al. (2013) state that the development of coastal border areas should use a balanced approach to economic and ecological growth based on the interests and potential of the community.

Rural development becomes the foundation, supporter and determinant of development for the region, urban area, even the nation and the state, because in the rural area lies the reality of community life that has many potentials. It supplies basic needs, from agriculture, plantation, animal husbandry and fishery as well as becomes the location of tourism. If the development of the village and its people are not able to empower its potential and increase its productivity, there will be problems such as urbanization, unemployment, and poverty, and even the village will be abandoned by its people in order to become migrant workers. The spirit of developing the village is a manifestation of the ideal development concepts of participatory, democratic, socio-economic based and sustainable development. According to Luthfia (2013), development in the village is a determinant and critical in determining urban development. Sulaiman et al. (2017) emphasize that village development is the foundation and determinant of regional and national development successes, as villages have resources that can meet the needs of agriculture, plantation, livestock, fisheries and tourism. 
The importance of rural development, including development in border and coastal areas, is one of the essential areas of study and program, especially in the framework of maintaining sovereignty, nationalism and justice by accelerating the distribution and welfare of rural communities. It is essential and strategic to develop border areas because developing border and coastal areas are an integral part of national development. Based on Law Number 26 the Year 2007 on Spatial Planning, in addition to Government Regulation of Republic Indonesia Number 26 the Year 2008 on National Spatial Plan, it is said that the border area classified as a strategic area where a spatial arrangement prioritized in the implementation of development. According to Law No. 6 of 2014 on villages, in Article 13, it is stated that the government can initiate the formation of villages in areas that are specific and strategic for the national interest. The interpretation of the article on "special and strategic areas" refers to the outermost areas of state borders, transmigration programs and other programs that considered strategic.

Based on the findings of Syamwil et al. (2005) from housing and settlement expertise group, architecture department of Institut Teknologi Bandung in 2005, the development of periphery region especially needs to see border as potential area which can boost economic growth based on the utilization of mutually beneficial relations between countries in a peaceful atmosphere. According to Patriadi (2010), border areas have their uniqueness, in terms of geographical, social, and cultural aspects. Thus, the management of border areas requires a comprehensive policy, as it aims to create and enhance economic and trade activities between the two countries and will impact on improving the welfare of local communities and increasing state revenues through export and import activities. Sholihah (2016) states the border areas are strategically valuable in the success of national development and improving the socio-economic welfare of surrounding communities. However, development in the border and coastal areas still has challenges and problem, as stated in the findings of Widiati (2007) that explain the handling of border areas between countries has more problems than the achievement of development progress, there are the gap of facilities and infrastructure between the two countries, land transportation, telecommunications, electricity, information, and other infrastructure.

In addition, the disturbance of bilateral relations on the border is related to security and political aspects as well as violations in the management and exploitation of natural resources across borders on land and sea. Furthermore, based on a review report of the Regional Development Planning Agency (Bappeda) of West Kalimantan in 2016 the border condition has not changed much, primarily to compete with the rapid development of border areas from neighboring countries, such as Sarawak Malaysia which is able to build growth centers on the border through various activities such as economic and trade that have benefited both the government and its people.

In the reform era with prolonged critical conditions, the management of border issues cannot be done optimally (Sutisna et al., 2010). In the planning process, one of the border area management issues is that there has not been provided with an integrated and detailed development plan (BappenasBNPP 2010). The border area is generally a lagging region with conditions prone to ideological, political, economic, and socio-cultural aspects, as well as defence and security. The most prominent phenomenon is the rampant of illegal logging, illegal trading, illegal trafficking, and the shifting of boundaries between countries (Idris \& Sijabat 2011). The border communities are generally poor and economically more oriented to neighbouring countries-by conducting temporary or permanent migration with the main economic motive, as it occurs along the border area of West Kalimantan with Sarawak (Arifin 2011). The development policy model used by the government is irrelevant to the characteristics of the region such as a bureaucratic culture that is still sectorial, the weakness of the border management authority, the inconsistency of technical policy with the border development paradigm, and the isolated geographical condition require extra-ordinary handling (Arifin 2013). Most of the border areas are relatively lagging and have not improved the welfare of the society and had gap with neighbouring countries, this is due to the limited social, economic facilities and infrastructure such as transportation facilities and infrastructure, telecommunications, settlements and the low quality of human resources that is imbalanced with the nature potentials (Gevisioner 
el al. 2013) \& (Sholihah 2016). Coastal communities sometimes forgot because the government policies are focused on development only. The welfare of fishers getting worse because of the decreasing of fishing targets, even overfishing, and the narrowing of fishing ground. On the other hand, the necessities of life are higher worsen by the destruction of the water environment and its ecosystem by human and natural disaster (Indarti \& Wardana 2013). Meanwhile, Kristiyanti (2016) also emphasized that communities around the coast are experiencing a downturn, because they have not been able to manage coastal resources optimally and they have limited knowledge about the use of resource development in the coastal areas, and do not know other useful and innovative ways to manage the coastal resources they produce.

Based on the background of the importance of development in the village, especially the border and coastal areas and the problems found, we are interested in creating a model of community empowerment in the coastal border area based on ecotourism, precisely in Sebubus Village and Temajuk Village, Paloh Subdistrict, Sambas District, West Kalimantan.

\section{Research Methods}

The study was conducted in 2018 and used Participatory Rural Appraisal (PRA). According to Daniel et al. (2008) PRA is a rural understanding based on widespread participation by approaching the selection, identification and calcification of existing problems within a rural area. Data is collected through 1) Brainstorming to accommodate various aspirations, ideas, and suggestions; 2) Focus Group Discussion (FGD) to discuss a problem in a focused way; and 3) Participatory Decision Making (PDM) to make a decision (Huraerah 2011). The research location was determined in Sebubus Village and Temajuk Village, Paloh Subdistrict, Sambas District, West Kalimantan Province, considering that besides being a coastal area and border with Sarawak Malaysia, these villages are also areas that have great potential as a tourist village.

The study used purposive sampling to determine the informant or research subject selected on the consideration of the researcher that the informant or research subject can be useful to meet the needs and objectives of the study. The research informants as many as 35 people consisting of pioneer activists and empowerment activists, village government, community leaders, business groups, academics and tourist visitors and data analyzed through SWOT analysis with internal factors are: Strength and Weakness, and external factors are: Opportunities and Threats (Rangkuti 2014) and (Fatimah 2017).

\section{Results and Discussion}

Sambas District has a village on the western edge of Borneo island that is Temajuk Village which formed in 2002 as the extension of Sebubus Village. It located near Natuna Sea and northern territory which is directly adjacent to Sarawak State. Sambas District has an area of 6,395.70 km2 or 639,570 ha, about $20.12 \%$ of Paloh Subdistrict, is located in the northern part of the western coast of West Kalimantan province with a coastline of $\pm 128,5 \mathrm{~km}$ and length of state border $\pm 97 \mathrm{~km}$. Based on the observation and analysis of monograph documentation of Temajuk Village in 2018 the uniqueness and attractiveness of Temajuk Village is due not only to its nature as a coastal and border area but it is also an area that has excellent potential as a tourist destination to become Tourism Village.

Types of tours offered are natural attractions of flora and fauna, mangrove tourism area, turtle conservation, Tugu Garuda Monument, Bajulang Stone, Gunung Pangi Waterfall, coral reef, Camar Bulan Quayside, and various beaches such as Surya, Batu Nenek, Maludin, Atong Bay, Pasir Plaik and Tanjung Datok. Community livelihoods in Temajuk Village are mainly fishermen, carpenters and construction workers, farmers and farmworkers of rubber, coconut and pepper plantation and coastal tourism entrepreneurs. The level of education is generally as follows Elementary School (51.40\%), Junior High School (22.15\%), Senior High School (24.42\%) and Higher Education (2.03\%).

This study has several stages of activities, that are 1) A preliminary study on 2017 to 2018 about development and empowerment in the coastal border areas, namely a) Conducting a literature 
review of scientific journals and research findings, the study of mass media both print and online; b) Conducting discussions with practitioners and experts on the results of a literature review, the results can formulate problems, objectives, location and method of research; and c) Preparing and submitting a research plan; 2) Designing and implementing the research agenda on January 2018 such as a) Conducting discussions with research teams and colleagues especially crucial informants; b) Determining the instruments and research informants as well as the schedule of activities; and c) preparing research supplies and equipment. 3) Conducting research on February to April 2018 with the activities a) Opening access and asking for permission to the location of the research through critical informants; b) Conducting in-depth interviews and dialogue with informants: empowerment activists, community leaders, village government especially village leaders, youth and people engaged in economic and tourism business groups and visitors; c) Conducting direct observation by visiting the location of economic activities and tourist attractions; d) Processing and analyzing documentation data and research results; e) Clarifying and verifying data with informants; and f) Processing and analyzing data to create research reports and scientific articles.

\section{Ecotourism empowerment activist of coastal border society}

Actors and activists of empowerment are those who have the spirit, ideas, initiation, have access and can interact, eliminate, facilitate and mobilize the community to do the empowerment program. The empowerment communicator comes from young activists who have high awareness and enthusiasm to advance Sebubus Village and Temajuk Village which before 2002 was still one of the hamlets of Sebubus Village. The empowerment communicator was pioneered by Darmawan as chairman of the Kalilae group, as a youth activist that had a college education and active in the organization. He has idealism, interpersonal communication skills, good access and cooperation with others, ideas and implementation of empowerment programs. He collaborated with Gustian, a youth activist from Temajuk, Chairman of the Camar Bulan Farmer Group and other youths who joined together with some community leaders who share the same passion and purpose for the progress of the village.

Youth activists as the pioneer of empowerment is an essential asset in rural development, in the midst of many young people leaving the village and the generation of farmers is decreasing because they think working in the city (urbanization) is more promising for their welfare so that the awareness and high spirit of youth activists are an excellent step to carry out development based on the potentials of the village both from agricultural resources, fisheries, and tourism. Because according to Gustina (2007), the younger generation has a lot of communication access that used, because the curiosity of young people tends to be higher towards information. Susanti (2009) and Purwatiningsih (2012) stated that the thinking and participation of youth leaders usually generate new ideas (innovation) and give more colour in the preparation of development planning in the village.

Activist, pioneers of empowerment can be called opinion leaders who can influence and invite other youths as well as some community leaders who care about development in the village. Opinion leaders characterized by higher formal education status, higher exposure media, more cosmopolitan and more experienced, empathic ability, greater social participation, and innovative in accepting and adopting new ideas (Nurudin 2005, Iqbal 2007, Badri et al. 2008) and other empowerment actors come from community leaders who have long worked as farmers, fishers and traders as well as former government officials who joined the village empowerment pioneers. These actors have experience and are well acquainted with the problems and potential of the village. Youth activists are a group of young people who continue the work of their parents in the village as farmers, fishers and do not continue their education to college. Young pioneers as empowerment communicators supported by community leaders and village youths are the driving force in the gradual development of the village and can be referred to as community development drivers. According to Ife and Tosoriero (2008), community development is a process of facilitating the re-establishment of community structures as a new way to organize social life in meeting the needs, mobilizing resources, skills and wisdom of the community itself. Hasim \& Remiswal (2009) stated community development as a strategy in social development by community members to work together to achieve the future of the community itself. 
However, the empowerment activist as the opinion leader and community development is not fully supported by the village government both in the program and budget policy so that the role of community development is still at the individual, family and small group stage and can not yet enter the village government organizations and the whole community. As according to Suharto (2007) community development or community development is one of the unique approaches and methods of social work and involves handling problems from two levels: individuals, families, and groups (micro-level), then organizations and communities (macro-level). The focus of community development is essentially a planned social change strategy that is professionally designed to address problems or meet the needs at the community level.

The lack of support from the village government towards community development is due to the vast area of Sebubus village, which reaches 326210 hectares and Temajuk village, which has an area of 2,300 hectares. Development programs still tend to focus on government and administration expenditures and physical development, while less attention to empowerment programs. So that community participation, especially in doing development planning, is generally not running, and people do not dare to convey their aspirations. People are more likely to get busy doing the routine activity to earn a living by farming, becoming fisherman and farm labourer. The empowerment communicators, as the opinion leader and the community development actors have conducted a personal dialogue and group communication both informally and formally in the forum of village development planning on the importance of ecotourism empowerment program related to conservation and mangrove tourism, honey farming (kelulut) in the mangrove area and processing of mangrove fruit, but has not succeeded in becoming the primary concern of the village development program. Although there are empowerment activities as well as assistance from the agricultural service and the marine and fishery agencies of the district, it was only counselling and training activities, not mentoring and partnerships so that the empowerment program has no sustainability and has no positive impact on the community. Whereas according to the Minister of Home Affairs Regulation No. 33 of 2009 on the guidance of ecotourism development in the region, in order to develop ecotourism in the region optimally it is necessary to have planning strategies, utilization, controlling, institutional strengthening, and community empowerment by taking into account social, economic, ecological, and involving stakeholders. Similarly, according to Flamin and Asnaryat (2013), Haryanto (2014) and Karlina (2015), the management of ecotourism requires cooperation between stakeholders both from the government, community and private parties.

There are other community empowerment activists outside the society, namely the World Wide Fund (WWF), an international non-governmental organization that carries out environmental mitigation, conservation and environmental restoration activities. WWF conducts research and empowerment on mangrove conservation and turtle conservation in Sebubus Village and Temajuk Village, Paloh Subdistrict. However, WWF has not been empowering local people to improve their knowledge or skills further and can not cooperate with local activists. WWF involves activists of empowerment and local communities only to support ceremonial activities and the publication of their work. By having stronger resources, programs and access WWF should be able to empower activists and local communities in order to improve their competence in community development. Ideally, empowerment communicators can synergize empowerment activist of youth and community leaders and WWF as a civil society with local governments from village to district level, including with companies in Sambas in conducting joint programs to promote the potential of Sebubus Village and Temajuk Village.

The village and local governments make development policies by providing more open (democratic) opportunities for the community in this case empowerment activist as civil society in giving aspiration and participation according to problems faced and potential owned. Government with related offices prioritize development programs through empowerment to be able to increase human resources in the form of spirit, awareness, knowledge, skills and independence as well as natural resources and economic resources of the community. Empowerment activists can become facilitators, instructors, mentors and partners in empowerment programs both with the government and with the private 
sector. Furthermore, the private sector supports the policy and empowerment program that has been agreed by implementing the obligation to run the Corporate Social Responsibility (CSR) program. The obligations of the private sector to implement CSR are contained in Law No. 40 of 2007 on Limited Liability Companies. According to Article 1 (3) social and environmental responsibility is the company's commitment to participate in sustainable economic development in order to improve the quality of life and the environment that is beneficial for the company itself, the local community, and society in general. The synergy between government, civil society and the private sector in development affirmed by Nugroho (2003), Sumarto (2004), Dwiyanto (2005), and Christian (2016) who stated that development is not only a government task but also requires various roles and other actors are civil society and private.

\section{Border coastal community empowerment model}

Empowerment activists as opinion leaders and community development actors have an essential role in developing the potentials of Sebubus and Temajuk villages and synergizing them with government and private or corporate sectors. In the process of development and empowerment, there is communication between civil society activists, government and private sector, stakeholders and experts, facilitators, instructors, extension workers, resource persons, volunteers and companions. According to Nurcholis et al. (2009), Mardikanto (2010), Buddenhagen and Baldwin (2011), some actors communicate in development to plan and implement programs, i.e. stakeholders. Pambudy (2009) states that the communication function in the implementation of development becomes essential in the success of the development, especially for the stakeholders or the empowerment activist to provide motivation, provide education and manage the community in a participative manner. Kusumedi \& Rizal (2010), Reinwald \& Kraemmergaard (2012) affirm that the role of development actors involved in each planning process has an influence on development policy and can transform the public interest into the interests of the government and engage in the implementation process of the development program.

Empowerment activists as development communicators in Sebubus and Temajuk villages have the idealism and passion for developing the potential of natural resources, especially conservation and mangrove tourism, coastal tourism and turtle breeding. Empowerment activists play a role in enhancing knowledge, motivation, experience and skills for the development of potential, especially conservation and coastal tourism, mangrove forests, fisheries and agriculture. This is accomplished by the support of various government empowerment programs in the form of counseling, training and comparative studies from the Department of Marine Affairs and Fisheries Sambas District, Conservation Agency and Natural Data Sources (BKSD) and Development of Coastal Areas Tangguh (PKPT) from the Ministry of Marine Affairs and Fisheries during year 2015-2017. The results of the implementation of the empowerment program include a conservation tourism area under the name of Ecotourism Mangrove in Sebubus Village. There is also a honey farm where the nest made around Mangrove Ecotourism area, processing of mangrove fruit that produces syrup products, jam, flour to make cake and chips. Other empowerment from the District Agricultural Service Agency in the form of counselling and training of organic fertilizer, cultivation of shallots, rice, pepper, horticultural agriculture, and training of rattan handicraft and comparative study of wood processing. Likewise, the Atong bay tourism area also received attention and assistance from Sambas Regency government in the form of homestay made close to the beach as an attraction for tourists to visit and stay to enjoy the beauty of the beach. It is in line with Aryunda (2011) research results, Karlina (2015); Salakory (2016) that ecotourism can be developed through the construction of mangrove facilities and infrastructure, increasing the capacity and competence of human resources, especially in mangrove management, designing ecotourism websites and coordinating with the government.

The participation of empowerment activists in activities such as counselling, training and comparative studies outside the region is a form of good development communication network. The communication network, according to Ramirez (2013), Cindoswari (2012), is a process of communication with the adoption of innovation obtained from outside communities to be model and applied in the community. Littlejohn and Foss (2008) mentioned that communication networks serve to manage information, 
build individual and group cohesiveness on similar interests and orientations, increase motivation and influence, exchange potential and resources. According to Eriyanto (2014), the communications network is a linkage of individual relationships with interpersonal communication and can also with group communication that occurs in society.

Empowerment activists recognize the importance of access to development communication networks so that they utilize all existing communications media development, both conventional as interactional media in the form of seminars, discussions, workshops, counselling, audiences with government, training and comparative study or by utilizing new media such as internet through publication of both opinion papers and publication activities.

The effectiveness of empowerment communication determined by the empowerment activist and also by the empowerment medium that used. According to Leeuwis (2006), media in communication empowerment consist of conventional communication media, interpersonal communication media and hybrid communication media or based on Information Communication and Technology (ICT). The empowerment activists in implementing the village potential development program have not maximized the use of communication media as a source of information in Sebubus and Temajuk villages due to difficulties in obtaining or not being available. The role of providing information, knowledge and increase the spirit to the public mostly through conventional media such as bulletin boards in the secretariat of empowerment organizations, mangrove ecotourism places and in the village office as well as the distribution of brochures. Media radio, newspapers and magazines and television are still tricky to access and used as a source of information empowerment.

The activist of empowerment has done communication in empowerment through interactional media by always conducting informal dialogue activity either at home or install in discussing problem faced, plan of activity program to be implemented and proposed an evaluation activity. However, they still have problems conveying the idea of conservation and tourism development program and mangrove product in development communication through the Forum of Village Development Planning (Musrenbangdes). Proposals at the neighbourhood and hamlet levels can be drawn up, but when it comes to the Musrenbangdes stage, it can not be fully accommodated, as programs and budgets for community and environmental empowerment still marginalized by procurement and management programs in the areas of public administration and infrastructure. It is in line with previous research findings that Musrenbangdes still dominated by the interests of local elites and prioritizes physical development and infrastructure rather than for the empowerment of the people's economy. The results of the study indicate that there are still low levels of stakeholder access in every stage of communication forum activities such as the lack of citizen participation, openness of the forum, and the low intensity of dialogue activities. The government's response to community aspirations in Musrenbangdes is not yet maximal and is still far from what is needed by the community. The orientation of the development program still tends to infrastructure development rather than the empowerment program (Mahmud 2007, Susanti 2009, Koswara 2010, Satries 2011, Salahuddin 2012, Solaiman 2013).

Therefore, empowerment activists are more likely to seek opportunities and establish communication networks and cooperation with parties outside the village either to colleagues, non-governmental organizations and the central government. Academics can support empowerment activists from universities bothwithlecturersandstudentsinresearchactivities, workpracticesorinternships, practicum and community service activities (KKN). Direct program support from both district, provincial and national governments can also be obtained as long as the empowerment activists proactively propose it. The government should also have priority development programs and budgets in border and coastal areas such as Sebubus Village and Temajuk Village. Because according to Amanah (2010) to overcome the gap that occurs between the condition of coastal communities with the conditions to achieved there mustbe efforts throughparticipatory, dialogical, andmotivatingdevelopmentcommunicationprocesses.

Communication in empowerment by empowerment activist and government can also use media of Information Technology and Communication (ICT) which have been done by potential tourists by 
accessing information of tourism potency in Sebubus Village and Temajuk Village through website, blog and research journal. There is a communication model of development through the use of media as pointed out by Sulaiman et al. (2016) that local governments and village governments can utilize conventional media such as notice boards and Internet-based information technology media in the form of websites to realize participatory, informative, transparent and accountable development programs to the public.

The attention of local and central government, especially the security officers, is only done when there is conflict in the border area, especially in Temajuk Village area, which borders directly with Melano Malaysia. The conflict occurred due to the shifting marks or boundary marks of the territory, the seizure of land for palm and pepper plantations, and logging cases in the forest. The conflict had heated up and became a national issue during the borderland dispute of Camar Bulan in 2011. The form of government attention at that time was still reactive and only limited to the security field, especially about the border area. Nevertheless, currently, there has been a process of opening access road between Sebubus and Temajuk villages, including ecotourism location, which began in 2017. According to Karsudi et al. (2010) in the development of ecotourism management should be able to create a conducive security situation both within and outside the tourist area. Tanaya \& Rudiarto (2014) stated that developing community-based ecotourism concepts in addition to the social and economic dimensions of the village should also consider the political dimension.

In reality, attention to community empowerment programs has not been implemented optimally, comprehensively and sustainably. Supposedly, the empowerment program is designed and implemented with orientation on ecotourism development from motivation and cooperation to care for environment conservation, utilization of natural potency, especially coastal tourism and conservation of mangrove forest. Then by increasing the productivity of plantation products, fisheries and various types of food and beverages from the processing of mangrove fruit. In addition, by developing various game facilities around the beach such as venues by the beach volley sport, beach soccer, camping areas, outbound games of agility, sailboat and motorboat tours. Also, by establishing and enhancing the role of economic and entrepreneurial institutions that can support the concept of ecotourism.

Ecotourism development in Sebubus and Temajuk villages can be pursued as a form of creating employment and prosperity for the community. According to the Minister of Home Affairs Regulation No. 33 of 2009 on guidelines for ecotourism development in the region, that ecotourism is a potential natural resource, environment, and uniqueness of nature and culture, which can be one of the leading sector areas that have not been developed optimally. Then in Article 1, it is mentioned ecotourism is a natural tourism activity in a subject area by taking into account the elements of education, understanding, and support for natural resource conservation efforts, as well as increased incomes of local communities. According to Karsudi et al. (2010), ecotourism development run by the spatial arrangement, game attraction management, promotion and marketing, then the establishment of regulation and management of ecotourism organization. Hijriati and Mardiana (2014) stated that ecotourism influence socially could awaken the awareness to maintain and preserve the environment, then economically can create job opportunity and source of income of society. Aulia and Hakim (2017) affirm that the concept of ecotourism needs to be developed through the principles of natural resources and products produced by the community in a sustainable manner.

Nevertheless, the implementation of empowerment in Sebubus and Temajuk villages is only at the extension and training stage, but not yet sustainable, so it is less than optimal in the assistance and partnership on ecotourism. In addition, there is a weakness in the lack of synergy in managing ecotourism implemented by stakeholders as development actors either by the government, activists of empowerment and private sectors, and the lack of utilization of communication media empowerment. Those things will complicate the development of ecotourism.

The researcher constructed the results of research by modelling the empowerment of coastal border communities, as in Figure 1. 


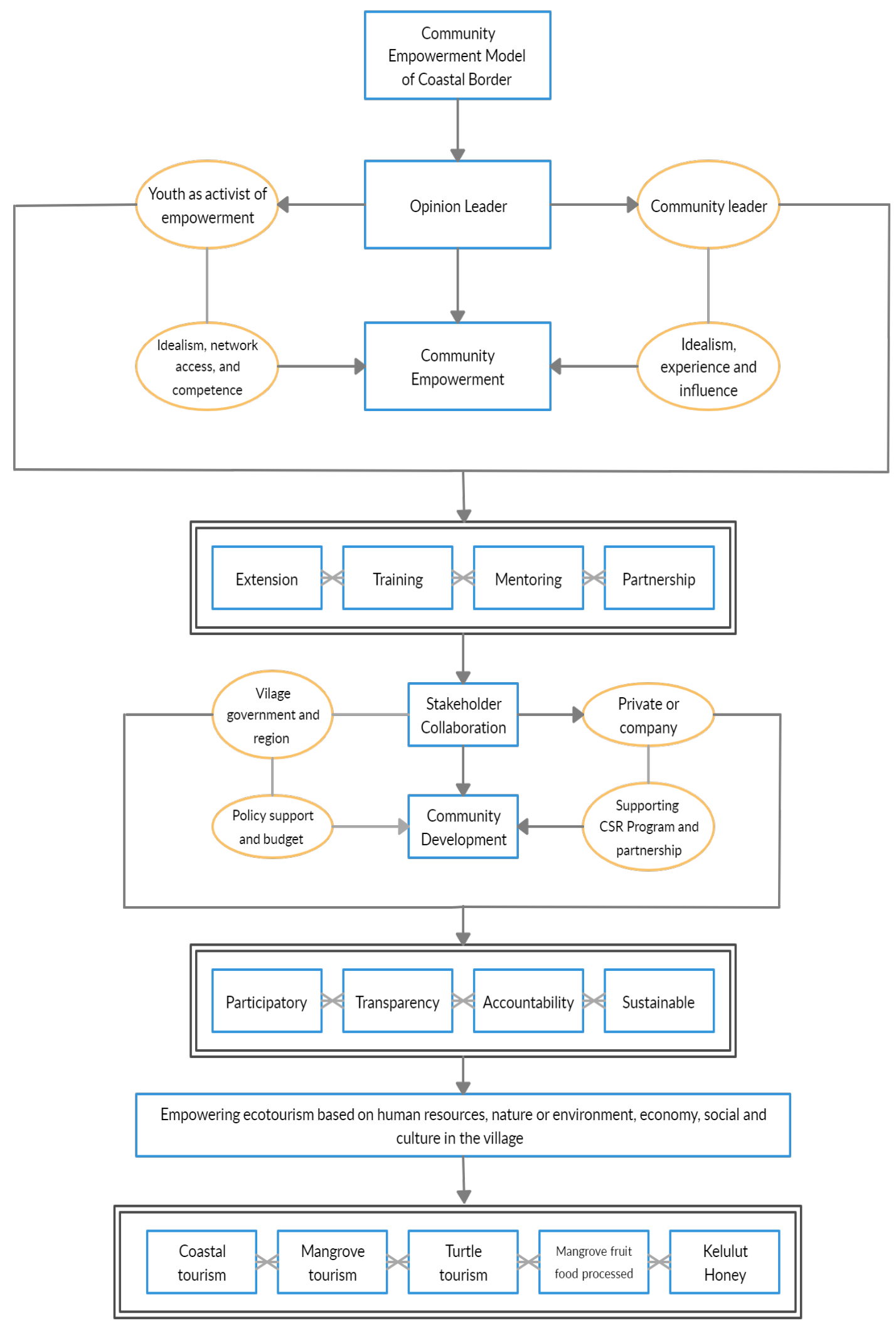

Figure 1.

Community Empowerment Model of Coastal Border

\section{Community boundary empowerment strategy}

Based on the findings, we as researchers have made a strategy of empowering coastal border communities by using SWOT analysis as presented in Table 1. 
Table. 1

SWOT analysis of empowering coastal border communities

\begin{tabular}{ll}
\hline \multicolumn{1}{c}{ Strength } \\
\hline & Youths who are pioneers of \\
& empowerment activists have idealism \\
& and access to develop ecotourism tom \\
& according to village potential. \\
& Support from several community \\
& leaders, business groups and youth \\
& who have the awareness and passion \\
& for developing the village potential. \\
& Sebubus and Temajuk villages have \\
& a lot of potential for ecotourism \\
& development with community \\
& empowerment, i.e. coastal tourism, \\
& mangrove conservation forest \\
& and turtle conservation along with \\
& mangrove processing, Kelulut honey \\
& and fishery. \\
& The people of Sebubus and Temajuk \\
village have the high work ethic to \\
earn a living, have carpentry skills, \\
and accustomed to become plantation \\
workers, especially oil palm, rubber \\
and pepper and to become fishermen.
\end{tabular}

Weakness

Uneven distribution of electricity service facilities, good road access and telecommunication and internet signals.

Empowerment activist programs lack support from village government and local government, especially in determining development program in the village.

Development programs in the village are still oriented to meet the needs of administration and government infrastructure while neglecting empowerment for ecotourism.

The association of tourism actors has little role in the tourism development program, especially in Temajuk village.

Opportunities
Many tourists come to visit Sebubus
Village and Temajuk Village to enjoy
the uniqueness, authenticity and
beauty of the beach.
Promotional media through the
internet about tourist attractions are
accessible to tourists.
Road access to Sebubus and
Temajuk villages are in the process of
development, including the road from
the Malaysian Melano border which is
closer to tourist sites.
Coastal conservation and coastal
areas in Sebubus and Temanjuk
villages have been the site of
conservation activities of international
NGOs World Wide Fund (WWF).
Threats

Many domestic migrants and foreigners persuade the public to sell land near the beach for a high price to be used as tourist sites, which consequently the community will lose their land assets.

The Communities are more dependent on the need for economic fulfillment that is cheaper, easier and closer.

Many people leave the village and pay less attention to the potential of the village, preferring to seek work in Melano Malaysia with higher wages.

The potential for conflict and waning nationalism due to social and economic inequality at the border of Temajuk Village, compared to Malaysia's Melano region, which is more prosperous because it has the attention of government and better infrastructure.

\section{So Strategy}

WO Strategy

Conducting counseling programs, training, mentoring and partnerships for ecotourism empowerment to develop all the potential of mangrove and coastal forests,

tourism management, post-harvest management, especially mangrove fruit.

Accelerate road construction and ecotourism development with the development of playgrounds, campsites, beach games facilities lodging and electric lighting.

Training on advertising and promotion techniques especially in socia media for promoting ecotourism and marketing.

ST Strategy

Ecotourism empowerment activists create awareness programs to protect and conserve the natural environment so as not to easily sale the land and forest and mangrove programs to overcome natural disasters.

Optimizing Corporate Social Responsibility (CSR) funds from palm oil companies for high education scholarships and supporting ecoempowerment programs.

Create task force consisting village government, community and security apparatus to enforce public order and security at border area especially for drug and illegal logging cases.
The high school administrators are proactive in proposing more scholarships for students in Sebubus and Tamajuk villages to continue their studies to universities.

Village and local governments provide policy and budget support for ecotourism empowerment implementation programs and propose improvements and development of facilities at ecotourism sites.

Village governments and activists of empowerment and private sectorts can work together for ecotourism development.

\section{WT Strategy}

Village and local governments raise awareness of land ownership, especially for economic and tourism businesses that must prioritize the preservation, future and welfare of rural communities.

Village and local governments provide more open opportunities for community participation in the planning and development process.

Village and local governments have priority in development planning for ecoempowerment programs to create and improve community welfare. 


\section{Conclusion}

Temajuk village has many potential beaches and fish products, while Sebubus Village has potentials for mangrove forest, turtle breeding, processed drinks and food from mangrove fruit. So it requires the management of ecotourism that can create jobs and improve the welfare of the community through empowerment programs, especially for the younger generation to become community-based tourism activists.

The aim of the empowerment program is the youth activists are pioneers and actors in Sebubus Village of ecotourism empowerment as well as opinion leaders who have idealism and can influence and cooperate with community leaders to develop and promote the village. Road infrastructure from Sambas to Sebubus Village is relatively good, except after the Sekura River which is damaged as it often passed by trucks carrying oil palm. While Temajuk Village still has problems with road infrastructure, electric lighting and telecommunication signal. They thus require local and central government policies to improve road and bridge infrastructure, electricity facilities and internet access for communication in supporting tourism access to Sebubus and Temajuk villages.

The empowerment of ecotourism has not been carried out continuously, yet it has not become a priority for village development and private partnership, so the empowerment activists only get counselling, training, and comparative studies but are challenging to develop, due to the inadequate mentoring and partnership programs. The community empowerment program is carried out collaboratively and synergistically between the community, village and regional governments, universities, activists and the private sector.

The access of the border area from Melano Malaysia to the tourist sites of Temajuk village is closer, more accessible and better to travel, so people are still dependent on working as farmers, labourers and carpenters in Malaysia, including in terms of fulfilling the needs such as cooking oil, and rice. So that with the community empowerment program, there will be no dependency and can create jobs, provide basic needs of the community and develop tourism potential as a village economic power.

\section{References}

Amanah S (2010) Peran komunikasi pembangunan dalam pemberdayaan masyarakat pesisir. Jurnal Komunikasi Pembangunan 8(1):1-19. http://journal.ipb.ac.id/index.php/jurnalkmp/article/ view/5691.

Arifin S (2011) Migrasi penduduk dan implikasinya terhadap hankam di wilayah perbatasan KalbarSerawak. Jurnal Masalah-Masalah Hukum 40(2):220-227. https://ejournal.undip.ac.id/ index.php/mmh/article/view/10473

Arifin S (2013) Cross border approach sebagai alternatif model kebijakan pembangunan kawasan perbatasan. Jurnal Hukum Ius Quia Iustum 1 (20):37-58. DOI: 10.20885/iustum.vol20.iss1. art3.v.

Aryunda H (2011) Dampak ekonomi pengembangan kawasan ekowisata Kepulauan Seribu. Jurnal Perencanaan Wilayah dan Kota 22(1):1-16. http://journals.itb.ac.id/index.php/jpwk/article/ view/4130.

Aulia AN \& Hakim L (2017) Pengembangan potensi ekowisata Sungai Pekalen Atas, Desa Ranu Gedang, Kecamatan Tiris, Kabupaten Probolinggo. Jurnal Wilayah dan Lingkungan 5(3):156-167. DOI: 10.14710/jwl.5.3.156-167.

Bappenas-BNPP (2010) Draft Rencana Induk Pengelolaan Batas Wilayah Negara dan Kawasan Perbatasan. Decentralization Support Facility (DSF) BAPPENAS - BNPP- PT.Pillar Pusaka Inti. Jakarta.

Badri M, Hubeis M, \& Maksum (2008) Pemberdayaan komunikasi pemuka pendapat dalam penangananbencanagempabumi di Yogyakarta (Kasus Kabupaten Bantul). Jurnal Komunikasi Pembangunan 6(1):55-71. https://journal.ipb.ac.id/index.php/jurnalkmp/article/view/5660. 
Buddenhagen RW \& Baldwin JR (2011) Performing communicative functions in development projects: An exploratory study of development practices in Tanzania. International Journal of Intercultural Relations 36(3):418-429. DOI: 10.1016/j.ijintrel.2011.11.001.

Cindoswari AR (2012) Jaringan komunikasi dalam penerapan teknologi produksi ubi kayu. Thesis, Institut Pertanian Bogor.

Christian R (2016) Penerapan prinsip-prinsip good governance dalam pelayanan publik dalam pada dinas tenaga kerja Kota Samarinda. eJournal Ilmu Adminitrasi Negara 4(2):2781-2794. https://ejournal.an.fisip-unmul.ac.id/site/?p=1987.

Daniel M, Darmawati, \& Nieldalina (2008). Participatory Rural Appraisal (PRA): Pendekatan Efektif Mendukung Penerapan Penyuluhan Partisipatif dalam Upaya Percepatan Pembangunan Pertanian. Jakarta: Bumi Aksara.

Dwiyanto A (2005) Mewujudkan Good Governance Melalui Pelayanan Publik. Gadjah Mada University Press.

Eriyanto (2014) Analisis Jaringan Komunikasi: Strategi Baru dalam Penelitian Ilmu Komunikasi dan Ilmu Sosial Lainnya. Jakarta: Prenada Media Group.

Fatimah FND (2017) Teknik Analisis SWOT: Pedoman Menyusun Strategi yang Efektif dan Efisien serta Cara Pengelola Kekuatan dan Ancaman. Yogyakarta: Anak Hebat Indonesia.

Flamin A \& Asnaryati (2013) Potensi ekowisata dan strategi pengembangan Tahura Nipa-Nipa Kota Kendari Sulawesi Tenggara. Jurnal Penelitian Kehutanan Wallace 2(2):154-168. DOI: 10.18330/jwallacea.2013.vol2iss2pp154-168.

Gevisioner, Bangun R, \& Karyanti (2013) Strategi pembangunan berbasis masyarakat di kecamatan perbatasan negara di Provinsi Riau. Jurnal Bina Praja 5(1):53-62. DOI: 10.21787/ jbp.05.2013.53-62.

Gustina A (2007) Jaringan komunikasi dan peran perempuan dalam mempertahankan budaya rudat: Studi pada masyarakat Desa Negeri Katon, Kecamatan Negeri Katon, Lampung Selatan. Thesis, Institut Pertanian Bogor.

Haryanto JT (2014) Model pengembangan ekowisata dalam mendukung kemandirian ekonomi daerah studi kasus Provinsi DIY. Jurnal Kawistara 4(3):225-330. DOI: 10.22146/kawistara.6383.

Hasim \& Remiswal (2009) Community Development. Berbasis Ekosistem: Sebuah Alternatif Pengembangan Masyarakat. Jakarta: Diadit Media.

Hijriati E \& Mardiana R (2014) Pengaruh Ekowisata Berbasis Masyarakat terhadap Perubahan Kondisi Ekologi, Sosial dan Ekonomi di Kampung Batusuhunan, Sukabumi. Jurnal Sosiologi Pedesaan 2(3):146-159.

Huraerah A (2011) Pengorganisasian dan Pengembangan Masyarakat: Model dan Strategi Pembangunan Berbasis Kerakyatan. Bandung: Humaniora.

Huruswati I, Kurniasari A, Purwanto AB, \& Sabeni M (2012) Evaluasi Program Pembangunan Kesejahteraan Sosial di Desa Perbatasan Kalimantan Barat. Jakarta: P3KS Press.

Idris I \& Sijabat S (2011) Model peningkatan peran KUMKM dalam pengembangan komoditas unggulan di kawasan perbatasan. Jurnal Pengkajian Koprasi dan UKM 6(1):89-123.

Ife J \& Tesoriero F (2008) Community Development: Community Based Alternatives in an Age of Globalization. Australia (AU): Pearson Education.

Indarti I \& Wardana DS (2013) Metode pemberdayaan masyarakat pesisir melalui penguatan kelambagaan di wilayah pesisir Kota Semarang. BENEFIT Jurnal Manajemen dan Bisnis 17(1):75-88.

Iqbal M(2007)Analisis peran stakeholder dan implementasinya dalam pembangunan pertanian. Jurnal Litbang Pertanian. Pusat Analisis Sosial Ekonomi dan Kebijakan Pertanian 26(3):89-99.

Karlina E (2015) Strategi pengembangan ekowisata mangrove di kawasan Pantai Tanjung Bara, Kutai Timur, Kalimantan Timur. Jurnal Penelitian Hutan dan Konservasi Alam 12(2):191-208. 
Karsudi, Soekmadi R, \& Kartodihardjo H (2010) Strategi pengembangan ekowisata di Kabupaten Kepulauan Yapen Provinsi Papua. Jurnal Manajemen Hutan Tropika 16(3):148-154.

Koswara (2010) Strategi Penyelarasan Penyusunan APBD dengan RPJMD untuk meningkatkan pembangunan sarana dan prasarana di Kota Bekasi. Thesis, Institut Pertanian Bogor.

Kristiyanti M (2016) Pemberdayaan Masyarakat Pesisir Pantai melalui Pendekatan ICZM (Integrated Coastal Zoe Manajement). In: Kajian Multi Disiplin Ilmu dalam Pengembangan IPTEKS untuk Mewujudkan Pembangunan Nasional Semesta Berencan (PNSB) sebagai Upaya Meningkatkan Daya Saing Global, 28 July 2016. Semarang: Unisbank Semarang, 752-760

Kusumedi P \& Rizal AHB (2010) Analisis stakeholders dan kebijakan pembangunan Kesatuan Pengelolaan Hutan (KPH) Model Maros di Provinsi Sulawesi Selatan. Jurnal Analisis Kebijakan Kehutanan 7(3):179-193.

Leeuwis C (2006) Communication for Rural Innovation: Rethinking Agricultural Extention. Oxford: Blackwell Publishing Ltd.

Littlejohn SW \& Foss KA (2008) Theories of Human Communication 9th. Singapore: Cengage Learning.

Luthfia AR (2013) Menilik urgensi desa di era otonomi daerah. Journal of Rural and Development 4(2):135-143.

Mahmud A (2007) Model komunikasi pembangunan dalam penyediaan prasarana perdesaan di kawasan pesisir utara Jawa Tengah (studi kasus Desa Morodemak dan Purwosari Kabupaten Demak). Thesis, Universitas Diponegoro, Semarang.

Mardikanto T (2010) Komunikasi Pembangunan: Acuan Bagi Komunitas Akademis, Praktisi, dan Peminat Komunikasi Pembangunan. Surakarta: UPT Penerbitan dan Pencetakan UNS Pr.

Nurcholis H, Milwan T, \& Warsono H (2009) Perencanaan Partisipatif Pemerintah Daerah. Jakarta: Grasindo.

Nugroho ND (2003) Reinventing Pembangunan. Jakarta: Gramedia Elex Media Komputendo.

Nurudin (2005) Sistem Komunikasi Indonesia. Jakarta: PT Raja Grafindo Persada.

Pambudy R (2009) Pola komunikasi pembangunan dan kebijakan publik. In: Komunikasi Pembangunan Mendukung Peningkatan Kualitas Sumber Daya Manusia dalam Kerangka Pengembangan Masyarakat, 19 November 2009. Bogor: 67-77.

Patriadi HB (2010) Isu Perbatasan: Memudarnya 'Imagined State?, dalam Mengelola Perbatasan Indonesia Didunia Tanpa Batas, Isu, Permasalahan dan Pilihan Kebijakan. Yogyakarta: Graha Ilmu.

Purwatiningsih SD (2012) Efektivitas komunikasi pembangunan pada masyarakat sekitar Hutan Konservasi Taman Nasional Gunung Halimun Salak. Disertation, Institut Pertanian Bogor.

Ramirez A (2013) The influence of social networks on agricultural technology adoption. Procedia Social and Behavioral Sciences 79:101-116.

Rangkuti F (2014) Analisis SWOT: Teknik Membedah Kasus Bisnis. Jakarta: Gramedia Pustaka Utama.

Reinwald A \& Kraemmergaard P (2012) Managing stakeholders in transformational government - A case study in a Danish local government. Government Information Quarterly. GOVINF-00813:1-9.

Salahuddin (2012) Pengaruh komunikasi interaksional terhadap partisipasi masyarakat dalam musyawarah perencanaan pembangunan di Kota Kendari. Jurnal Stimuli Ilmu Komunikasi. 3:70-78.

Salakory RAJB (2016) Pengembangan ekowisata berbasis masyarakat di Kepulauan Banda, Kabupaten Maluku Tengah. Jurnal Ilmu Pertanian Agrika 10(1):84-92.

Salim N (2011) Analisis pola spasial kemiskinan, pembangunan manusia/sosial, dan aktivitas ekonomi, serta keterkaitannya di Provinsi Kalimantan Barat. Thesis, Institut Pertanian Bogor. 
Sarosa W (2011) Kebijakan Pengelolaan Kawasan Perbatasan Indonesia. Jakarta: The Partnership for Governance Reform.

Satries WI (2011) Mengukur tingkat partisipasi masyarakat Kota Bekasi dalam penyusunan APBD melalui pelaksanaan Musrenbang 2010. Jurnal Kybernan 2(2):89-130.

Sholihah I (2016) Kebijakan hukum pembangunan kawasan perbatasan melalui infrastruktur berbasis teknologi. Rechts Vinding 5(3):305-321.

Solaiman NF (2013) Responsifitas pemerintah dalam pembangunan daerah (Studi kasus di Desa Longpujungan Kecamatan Pujungan Kabupaten Malinau). eJournal Pemerintahan Integratif. 4(1):450-463.

Suharto (2007) Pekerjaan Sosial di Dunia Industri Memperkuat Tanggungjawab Sosial Perusahaan, Bandung: Refika Aditama.

Sulaiman AI, Lubis DP, Susanto D, \& Purnaningsih N (2016) Merancang media informasi dalam musyawarah perencanaan pembangunan Kota Banjar Provinsi Jawa Barat. Kawistara 6(1):93-106.

Sulaiman AI, Kuncoro B, Sulistyoningsih ED, Nuraini H, \& Djawahir FS (2017) Pengembangan agrowisata berbasis ketahanan pangan melalui strategi komunikasi pemasaran di desa. The Messenger 9(1):9-25.

Sumarto HS (2004) Inovasi, Partisipasi dan Good Governance. Jakarta: Yayasan Obor Indonesia.

Susanti (2009) Pengaruh partisipasi masyarakat terhadap proses musyawarah perencanaan pembangunan di Kecamatan Kapuas Kabupaten Sanggau. Jurnal Ilmu Administrasi 6 (3):293-305.

Sutaat (2012) Pemberdayaan masyarakat daerah perbatasan antar negara. Sosiokonsepsia 52(1):52-71.

Sutisna S, Lokita S, \& Sumaryo (2010) Boundary Making Theory dan Pengelolaan Perbatasan di Indonesia: Dalam Mengelola Perbatasan Indonesia Didunia Tanpa Batas, Isu, Permasalahan dan Pilihan Kebijakan. Yogyakarta: Graha Ilmu.

Syamwil IB, Pradono, \& Oetomo A (2005) Pembangunan Wilayah di Perbatasan Negara Kasus Kalimantan Barat. Bandung: Kelompok Keahlian Perumahan dan Permukiman Departemen Arsitektur Institut Teknologi Bandung.

Tanaya DR \& Rudiarto I (2014) Potensi pengembangan ekowisata berbasis masyarakat dalam pengembangan pedesaan di kawasan Rawa Pening, Kabupaten Semarang. Jurnal Teknik PWK 3(1):71-81.

Widiati A (2007) Kebijakan dan strategi penataan ruang kawasan perbatasan antarnegara di Provinsi Nusa Tenggara Timur. Jurnal Sains dan Teknologi Indonesia 9(3):110-119. 